\title{
The Exploratory Research of Chinese College Students' Leadership Trait
}

\author{
Chao Yufang \\ College of Business Administration \\ Qilu University of technology, \\ Jinan, China \\ chaochuwen@sina.com
}

\author{
Li Yuee \\ College of Business Administration \\ Qilu University of technology, \\ Jinan, China \\ lye@spu.cn.com
}

\begin{abstract}
The scale of Chinese college students is huge, and it is the source of China's future sustainable development. In twenty-first Century, leadership has become a scarce resource for various organizations. It is very good highly significant that doing well college Students' leadership, regardless of the country, or individual development. Modern leadership theory research shows that leadership trait is the basis of leadership, closely related to leadership development. College students are in puberty, and are good and have good development. Through the questionnaire survey, the correlation analysis, the Chinese college students' leadership characteristics were explored. Research shows that the Chinese college Students' leadership trait include the ideal, the forecast, the influence, the ability to distinguish, the honest, understanding, communication, power, emotion, etc.. In view of the development of these leadership traits, we should build the network system of family, school and community.
\end{abstract}

Keywords-leadership; china college; leadership trait; education

\section{INTRODUCTION}

Today, the college students are a special group. They are not only driving force of the society development, and are the main resource of the society construction. So, the level of comprehensive quality of college students basically can represents the level of country's talent and country's future development. In addition, the university period is a key development period in life. In this period, the college student's trait is of plasticity. So, if developing their leadership, it can get half the result with twice the effort. The foreign colleges' leadership development practice is all pay attention to the student leadership development and research, especially in American university as representation. In 2015, the scale of Chinese university graduates has been up to 750 million people, and the number of college students is the number one in the world. It is very key role and significant to china future development that improving their leadership.

\section{LITERATURE AND RESEARCH METHOD}

\section{A. Research Literature}

Leadership trait theory is the earliest and longest theoretical branch of leadership science. James M. Kouzes and Barry Z.Posner pointed that the top four leadership trait are honesty, vision, inspiration, ability through three times in detail investigations to thousand government administrative

Supported by College of Humanities and Social Sciences, Qilu University of technology support program for Outstanding Young Scholars; Natural Science Foundation of Shandong Province (ZR2013GM008), China departments and enterprises[1]. Peter F Drucker(1985) pointed out that leaders must learn the following habits acquired habits to maintain their effectiveness in the <the effective executive $>$ : dealing well with and use of time, pay attention to the contribution, finding and using well the person's ability, distinguishing the work of primary and secondary, making effective decision[2]. Robert House and Bernard Bass's charismatic leadership theory take better version, higher confidence, energy, enthusiasm, self-motivation, articulate, under personal risks and sensitivity of environment as the charismatic leader trait [3].

In china, Lin qiong and Fang Liluo(2002) take "the Chinese leadership traits factor scale" designed by Lin Wenshuan and Fang Liluo, and pointed out that trait of China's leading talents in twenty-first Century concluded four facts: effectiveness of the target, multi-faceted, personal qualities and interpersonal skills [4]. Zhao Guoxiang (2003) studied to the 180 mid-lever cadres, and pointed out that the leader should 7 kinds of ability: communication ability, innovation ability, organization ability and coordination ability, self-discipline ability, before the election with only ability, comprehensive decision-making ability, and strain capacity [5] Huang Xiaobin (2007) designed a more comprehensive leadership trait questionnaire. Reliability of the questionnaire was 0.8126, and the correlation coefficient reached a significant level $(\mathrm{R}>0.7)$, and questionnaire has good validity by the expert evaluation [6].

From the grasp of the literature, there is no specific questionnaire for college students' leadership trait identification, but related research provides a good basis for the study.

\section{B. Research Method}

This paper adopts literature research method, inductive method, reasoning method, questionnaire survey and correlation analysis method, and carry out the college student leadership trait exploratory research in Qilu University for example.

The research approach of this paper defines firstly definition of leadership; then designs the college student leadership questionnaire; further more analyzes the correlation between leadership trait and leadership level to determine the relevance of higher leadership traits. On this basis, the 
leadership development projects of college students are studied and designed.

\section{STUDY DESIGN}

Leadership is a kind of ability to promote the realization of the goal of leadership. This is very important significance for the individual to take on the leadership role. Therefore, the key to developing a leader is to enhance their leadership. [7]From this point and integrating leadership theory, leadership is a complex process, in which a person affects others to complete a mission, task, or goal. Therefore, the leadership evaluation index can be set from three aspects: goal setting, process, result, as shown figure 1 .

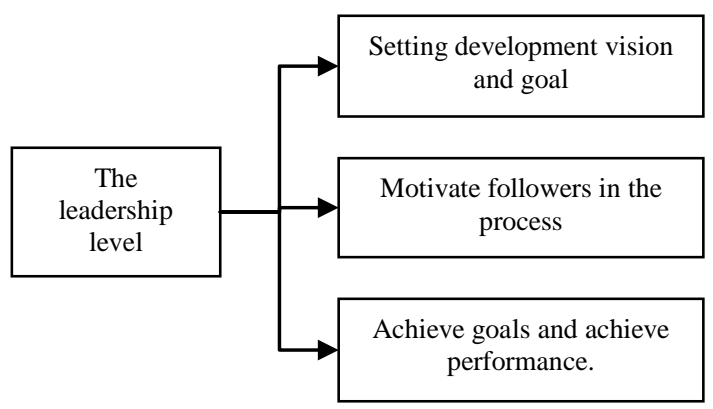

Fig. 1. The leadership evaluation model

As shown figure 1, the college student leadership can be evaluated from his vision and goal capacity, his motivate capacity and his team performance. According to this model, the college student leadership evaluation questionnaire is designed, as shown table 1 .

TABLE I. The COLLEgE STUDENT LEADERSHIP QUESTIONNAIRE

\begin{tabular}{|c|c|c|}
\hline Items & Items describe & Index \\
\hline 1 & $\begin{array}{l}\text { Often initiate or organize group activities (such as } \\
\text { class activities, fellow activities, etc.) }\end{array}$ & \multirow{4}{*}{$\begin{array}{l}\text { Setting } \\
\text { development } \\
\text { vision and } \\
\text { goal }\end{array}$} \\
\hline 2 & $\begin{array}{l}\text { able to integrate the views of members and form a } \\
\text { consensus for the event }\end{array}$ & \\
\hline 3 & $\begin{array}{l}\text { Be able to properly handle the relationship between } \\
\text { the members of the group and promote mutual } \\
\text { understanding to obtain the support and cooperation } \\
\text { in order to achieve activity goal }\end{array}$ & \\
\hline 4 & $\begin{array}{l}\text { Be able to raise and integrate the resources in many } \\
\text { ways in order to ensure the activity }\end{array}$ & \\
\hline 5 & $\begin{array}{l}\text { attract new members in order to enable efficient } \\
\text { operation of activities }\end{array}$ & \multirow{5}{*}{$\begin{array}{l}\text { Motivate } \\
\text { followers in } \\
\text { the process }\end{array}$} \\
\hline 6 & $\begin{array}{l}\text { Be able to anticipate problems in the future and face } \\
\text { the difficulties in the activities, to actively think of } \\
\text { ways, and to inspire members do not give up }\end{array}$ & \\
\hline 7 & $\begin{array}{l}\text { To be able to encourage, maintain and stimulate the } \\
\text { enthusiasm of the work of others, to determine the } \\
\text { realization of the intended target }\end{array}$ & \\
\hline 8 & $\begin{array}{l}\text { Pay attention to the rules, to the urgency of the } \\
\text { affairs, the importance of priority levels, and then } \\
\text { there are plans, steps to arrange the process, to } \\
\text { ensure that the work in an orderly manner }\end{array}$ & \\
\hline 9 & $\begin{array}{l}\text { Understand other people's thoughts and feelings and } \\
\text { actions, make feedback. Can more quickly establish } \\
\text { interpersonal relationships }\end{array}$ & \\
\hline 10 & $\begin{array}{l}\text { Formed the center of the group as soon as in } \\
\text { participated group activities }\end{array}$ & \multirow{2}{*}{$\begin{array}{l}\text { Achieve } \\
\text { goals and } \\
\text { achieve } \\
\text { performance }\end{array}$} \\
\hline 11 & $\begin{array}{l}\text { The group or team that Participated often better able } \\
\text { to complete the intended target. }\end{array}$ & \\
\hline
\end{tabular}

\begin{tabular}{|c|l|l|}
\hline Items & \multicolumn{1}{|c|}{ Items describe } & \multicolumn{1}{|c|}{ Index } \\
\hline 12 & $\begin{array}{l}\text { Most activities can be recognized by other team } \\
\text { members }\end{array}$ & $\begin{array}{l}\text { Achieve } \\
\text { goals and } \\
\text { achieve } \\
\text { performance }\end{array}$ \\
\hline 13 & $\begin{array}{l}\text { The group activities that organized often can achieve } \\
\text { the intended target. }\end{array}$ & $\begin{array}{l}\text { The group activities that organized often give up } \\
\text { halfway }\end{array}$ \\
\cline { 1 - 2 }
\end{tabular}

In fourteen items, the fourth belongs to Belonging to a negative test question, others items are all positive test question.

Assessment scale for the college student leadership traits adopts the Xiao bin Huang's enterprise leader traits questionnaire in his doctoral thesis <the research of enterprise leader's performance--influence factors, evaluation methods $>$. The reliability of the questionnaire was 0.8126 , and it had good validity. In addition, the questionnaire is also more suitable for China's actual conditions, can be cited. In order to make the questionnaire more in line with the actual situation of college students, in view of the actual situation of college students, to remove twenty-second of the enterprise leadership positions in the time that the qualifications of the project.

On the basis of this, the university student leadership trait questionnaire is divided into four parts, which are quality, intelligence, ability and knowledge. Personal qualities include integrity, honesty and credit, and a sense of responsibility. Intellectual include insight ability and comprehend ability. Knowledge includes professional knowledge and comprehensive knowledge. Ability includes innovation ability, control ability, self-control ability and social ability.

The questionnaire take Likert 5-point scale, for each problem set "strongly disagree, disagree, not sure, agree and strongly agree" five options, the five options corresponding assignment for $1,2,3,4,5$.

Questionnaire investigation takes random survey. Questionnaire survey was taken in Qilu Industry University. a total of 110 was issued randomly, and effective recovery of 106, questionnaires effective rate of $96.36 \%$, the grade of the interviewees distribution as shown in Table 2.

TABLE II. THE QUESTIONNAIRE GRADE DisTRIBUTION

\begin{tabular}{|c|c|c|}
\hline Grade & Count & Percent \\
\hline freshman & 23 & $21.70 \%$ \\
\hline sophomore & 50 & $47.17 \%$ \\
\hline junior & 29 & $27.36 \%$ \\
\hline senior & 4 & $3.77 \%$ \\
\hline total & 106 & $100 \%$ \\
\hline
\end{tabular}

Because the questionnaire was distributed randomly in the QILU industry university and investigated location was mainly in the vicinity of the teaching building, the most of investigator are sophomore because the sophomore had more curriculums. The senior were few because they were graduation practice, or take examination. That reduced they not be in school. So, they were the least in all the respondents. 


\section{EXPLORATORY RESEARCH ON COLLEGE STUDENTS LEADERSHIP}

After the questionnaire, the data were further verified. Then, questionnaire reliability analysis and validity analysis were taken. Furthermore, the correlation analysis was taken between the college student traits and their leadership.

\section{A. The College Students Leadership Questionnaire Reliability and Validity Analysis}

SPSS19.0 software was used to test the reliability of College Students' leadership and leadership trait questionnaire, and the reliability analysis results were shown in Table 3.

TABLE III. The COLLEGE STUdENT LEADERSHIP Traits AND LEADERSHIP LEVEL QUESTIONNAIRE RELIABILITY ANALYSIS

\begin{tabular}{|c|c|c|c|}
\hline Questionnaire & Cronbach's Alpha & $\begin{array}{c}\text { Based on the standard } \\
\text { Cronbach's Alpha }\end{array}$ & Items \\
\hline $\begin{array}{c}\text { The college student } \\
\text { leadership trait } \\
\text { questionnaire }\end{array}$ & .792 & .812 & 14 \\
\hline $\begin{array}{c}\text { The college student } \\
\text { leadership level } \\
\text { questionnaire }\end{array}$ & .866 & .868 & 21 \\
\hline
\end{tabular}

As shown table 3 , the reliability of the two questionnaires was between 0.80 and 0.90 , reaching and more than 0.5 of the study needed. So, the two questionnaires had good reliability and can be used.

Expert team was set up to analysis the questionnaire validity. The seven experts on study leadership were choosing. Every expert audited the college student leadership trait questionnaire, and put forward his proposals to perfect questionnaire. The expert team holds that the college student leadership questionnaire had better validity.

\section{B. The Correlation Analysis}

On the basis, the correlation between the college student leadership trait and leadership level was be analyzed. Using the 106 samples data analyzed the correlation between the college student leadership trait and leadership level, as shown table 4

TABLE IV. THE QUESTIONNAIRE GRADE DISTRIBUTION

\begin{tabular}{|c|c|c|c|c|c|c|c|}
\hline Leadership trait & $\begin{array}{l}\text { Correlation and } \\
\text { leadership level }\end{array}$ & $\begin{array}{l}\text { Significantly } \\
\text { (bilateral) }\end{array}$ & Number & $\begin{array}{c}\text { Leadership } \\
\text { trait }\end{array}$ & $\begin{array}{l}\text { Correlation and } \\
\text { leadership level }\end{array}$ & $\begin{array}{l}\text { Significantly } \\
\text { (bilateral) }\end{array}$ & Number \\
\hline ideal & $.408^{* *}$ & .000 & 106 & $\begin{array}{l}\text { Predictive } \\
\text { power }\end{array}$ & $.400^{* *}$ & .000 & 106 \\
\hline confidence & $.235^{*}$ & .015 & 106 & ambitious & $.360 * *$ & .000 & 106 \\
\hline optimism & $.339 * *$ & .000 & 106 & influence & $.440 * *$ & .000 & 106 \\
\hline honest & $.378^{* *}$ & .000 & 106 & emotion & $.351^{* *}$ & .000 & 106 \\
\hline sincerity & .146 & .134 & 106 & communication & $.376^{* *}$ & .000 & 106 \\
\hline will & $.236^{*}$ & .015 & 106 & enthusiasm & $.306 * *$ & .001 & 106 \\
\hline energy & $.337 * *$ & .000 & 106 & education & $.286^{* *}$ & .003 & 106 \\
\hline physical & $.275^{* *}$ & .004 & 106 & knowledge & $.197^{*}$ & .043 & 106 \\
\hline Like Challenge & $.374 * *$ & .000 & 106 & Technical skills & $.225^{*}$ & .021 & 106 \\
\hline comprehension & $.278^{* *}$ & .004 & 106 & $\begin{array}{l}\text { Communication } \\
\text { skills }\end{array}$ & $.316^{* *}$ & .001 & 106 \\
\hline $\begin{array}{l}\text { Discrimination } \\
\text { ability }\end{array}$ & $.398^{* *}$ & .000 & 106 & & & & \\
\hline
\end{tabular}

As shown table 4, the higher correlated factors to the college student leadership level are ideal, predictive power, influence, or charm. Correlation coefficient between 0.400 and 0.350 factors are discrimination ability, honest, comprehension, communication, ambitious, emotion. The middle correlation coefficient factors are optimism, energy, enthusiasm, communicative skills. The low correlative factors are confidence, sincerity, perseverance, physical, intellectual, education, technical skills.

Above analysis results shown that a college student with higher leadership should has the ability of construct a shared vision, and then around the share vision set up corresponding target. They should effectively manage and implement the target through personal charm to influence the others in his team. Through this, they promote team tends to a successful outcome.

In order to better understand and apply the results of the analysis, it can be further sorted according to the correlation of College Students' leadership traits and leadership level, and then carry out effective leadership education development, as shown in table 5. 
TABLE V. TABLE STYLES

\begin{tabular}{|c|c|c|c|c|c|}
\hline Leadership trait & correlation & Leadership trait & correlation & Leadership trait & correlation \\
\hline influence & $.440 * *$ & ambitious & $.360 * *$ & comprehension & $.278^{* *}$ \\
\hline ideal & $.408^{* *}$ & emotion & $.351 * *$ & physical & $.275^{* *}$ \\
\hline Predictive power & $.400 * *$ & optimism & $.339 * *$ & will & $.236^{*}$ \\
\hline Discrimination ability & $.398^{* *}$ & energy & $.337 * *$ & confidence & $.235^{*}$ \\
\hline honest & $.378^{* *}$ & Communication skills & $.316^{* *}$ & Technical skills & $.225^{*}$ \\
\hline communication & $.376^{* *}$ & enthusiasm & $.306^{* *}$ & knowledge & $.197 *$ \\
\hline Like Challenge & $.374^{* *}$ & education & $.286^{* *}$ & sincerity & .146 \\
\hline \multicolumn{2}{|c|}{ The higher correlation leadership traits } & \multicolumn{2}{|c|}{ The middle correlation leadership traits } & \multicolumn{2}{|c|}{ The little correlation leadership traits } \\
\hline
\end{tabular}

\section{The Application of Study Conclusion}

Table 5 provides useful pointers for developing the college student leadership. According table 5, we develop the college student leadership should give priority to influence, ideal, Predictive power, Discrimination ability, honest, communication, Like Challenge; next concern ambitious, emotion, optimism, energy, communication skills, enthusiasm, education; finally concern Comprehension, physical, will, confidence, technical skills, knowledge, sincerity.

The personal traits are formed through the process of individual socialization. In this process, the community, schools and families are very important. These factors and individual together affect the personal traits. So the college student leadership traits development should too use of these factors. We should set up the college student leadership development system included community, school and family. These factors should harmonize and integrate to develop the college student leadership.

Firstly, community, school and family should coordinate to do the college student ideal education. Ideal determines a person's pursuit, and determines the sense of responsibility and mission. The ideal education is not a single factor to decide, community, school and family can all affect the ideal. These factors coordinate to build up the college student ideal, and to establish the ideal target in line with the direction of the social development.

Secondly, all sectors of society should actively offer opportunities for the college student to participate in social activities. Most of the leadership traits need cultivate and develop in the social interaction. The leadership level is too increasing in the practice. So, through the practice chance that community, school and family, the college student integrate into society, and apply what learned to his life and work, then take the leadership knowledge into their own leadership ability. So, family and school all should encourage student to in social activities. College should enlarge society activity in education and student evaluation. Family should convert ideas about education and student development. Community should take part in the college student leadership education and provide chances for student, let them take part in society activity.

Again, the college should actively carry out the general education of the development of College Students' leadership, and offer basic leadership courses. Knowledge, attitudes and skills required for effective leadership can be docked with general education in various professional fields, and leadership education can be used as an important part of general education courses at the undergraduate level. So, according to the above leadership traits, colleges should research and develop leadership curriculum, and should train the teach team.

Lastly, we should create a good family environment for the development of college students to establish philosophy and world view. Words and deeds of parents will be imperceptible influence on children, so parents should constantly improve their own self-cultivation, regulate their own behavior, which will have a positive influence on their children. In addition, children's self-confidence come from the family in a large extend. So, the parent' encourage is very important to the establishment of self-confidence. Therefore, parents should always encourage their children to help their children to establish a strong self-confidence, which is very important for the development of children's leadership awareness.

We must be fully aware of important of the family. The family must take part in the college student leadership development. The parent must communicate with the college student to take insight college student development.

\section{CONCLUSION}

This paper established level of leadership and leadership traits of college students' questionnaire. The correlation analysis between the college student traits and leadership level found that influence, ideal, predictive power, discrimination ability, honest, communication and like challenge are have higher correlation with leadership level; ambitious, emotion, optimism, energy, communication skills, enthusiasm and education have middle correlation with leadership level; comprehension, physical, will, confidence, technical skills, knowledge and sincerity have the lowest correlation with the leadership level.

Due to the factors in socialization in the process of development and perfection, therefore affect the college student leadership traits of culture was developed and the effects including society, school, family and the students themselves multi-level, multi-faceted personality traits. Social, family and school actively cooperate with them, to cultivate and develop the development activities, and to develop the leadership traits of college students. 


\section{REFERENCES}

[1] David M. Rosch, Analyzing the Effectiveness of Multisource Feedback as a Leadership Development Tool for College Students[J]. Journal of Leadership studies.2013(3)

[2] Amy E. Colbert. Assessing the trait theory of leadership using self and observer ratings of personality: The mediating role of contributions to group success [J]. The Leadership Quarterly.2012 (3)

[3] Bass, B M Bass\&Stogdill"S handbook of leadership:Theory. Research and managerial applications [M]. New York:Free Press.1990
[4] Ling Qiong, Fang Liluo. Leadership human traits questionnaire [J]. china human resource.2002.11.pp:36-37( In Chinese)

[5] Zhao Guoxiang. Study on 185 level leading cadres of personality traits [J].Psychological Science.2002.25（2）.pp:231-232( In Chinese)

[6] Fang Yufei. Research on the leadership education of college students in the United States [D]. Shang Hai. AST CHINA NORMAL UNIVERSITY.2008( In Chinese)

[7] Chen Jing. Research on the influencing factors and training strategies of College Students' leadership [D].Qing Dao:Qing Dao university. 2012. ( In Chinese) 